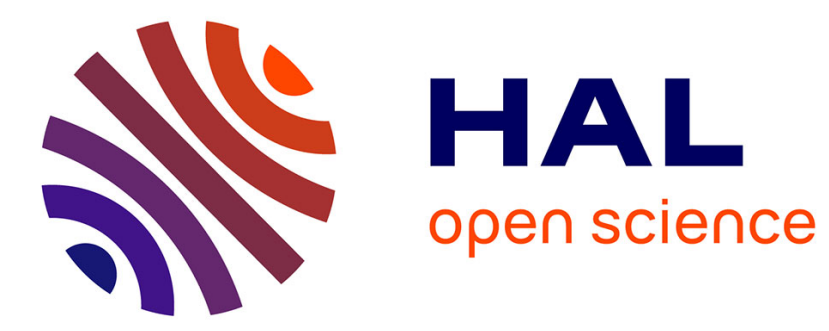

\title{
On the origins and the evolution of the fuel-cladding bonding phenomenon in PWR fuel rods
}

Clément Ciszak, Lionel Desgranges, Philippe Garcia, Catherine Sabathier, Laurent Fayette, Sébastien Chevalier

\section{- To cite this version:}

Clément Ciszak, Lionel Desgranges, Philippe Garcia, Catherine Sabathier, Laurent Fayette, et al.. On the origins and the evolution of the fuel-cladding bonding phenomenon in PWR fuel rods. Journal of Nuclear Materials, 2019, 520, pp.110-120. 10.1016/j.jnucmat.2019.04.015 . hal-03198832

\section{HAL Id: hal-03198832 \\ https://hal.science/hal-03198832}

Submitted on 15 Apr 2021

HAL is a multi-disciplinary open access archive for the deposit and dissemination of scientific research documents, whether they are published or not. The documents may come from teaching and research institutions in France or abroad, or from public or private research centers.
L'archive ouverte pluridisciplinaire HAL, est destinée au dépôt et à la diffusion de documents scientifiques de niveau recherche, publiés ou non, émanant des établissements d'enseignement et de recherche français ou étrangers, des laboratoires publics ou privés. 


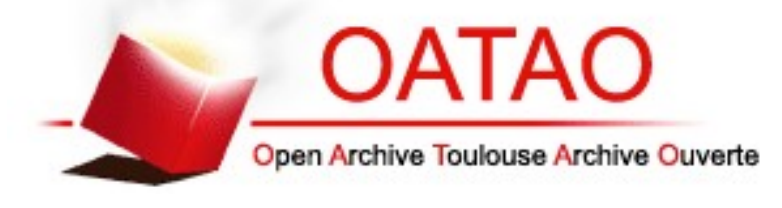

Open Archive Toulouse Archive Ouverte

OATAO is an open access repository that collects the work of Toulouse researchers and makes it freely available over the web where possible

This is an author's version published in: https://oatao.univ-toulouse.fr/27625

Official URL :

https://doi.org/10.1016/i.jnucmat.2019.04.015

To cite this version:
Ciszak, Clément and Desgranges, Lionel and Garcia, Philippe and
Sabathier, Catherine and Fayette, Laurent and Chevalier, Sébastien
On the origins and the evolution of the fuel-cladding bonding
phenomenon in PWR fuel rods. (2019) Journal of Nuclear Materials,
520. 110-120. ISSN 0022-3115

Any correspondence concerning this service should be sent to the repository administrator: tech-oatao@listes-diff.inp-toulouse.fr 


\title{
On the origins and the evolution of the fuel-cladding bonding phenomenon in PWR fuel rods
}

\author{
Clément Ciszak ${ }^{\text {a, b, * }}$, Lionel Desgranges a, Philippe Garcia ${ }^{a}$, Catherine Sabathier ${ }^{a}$, \\ Laurent Fayette ${ }^{\mathrm{a}}$, Sébastien Chevalier ${ }^{\mathrm{b}}$
}

${ }^{a}$ CEA, DEN/DEC, 13108, Saint-Paul-lez-Durance, France

b Univ. Bourgogne Franche-Comté, ICB Laboratory, UMR 6303 CNRS, 21078, Dijon Cedex, France

\section{H I G H L I G H T S}

- Fuel-cladding bonding in PWR fuel rods.

- Zirconia layer formed at the fuel.|cladding interface.

- Chemical bonding occurs between $\mathrm{ZrO}_{2}$ and $\mathrm{UO}_{2}$ at low burnups.

- Mechanical bonding progressively occurs between $\mathrm{ZrO}_{2}$ and $\mathrm{UO}_{2}$ when increasing burnup.

Keywords:

Spent fuel

Zircaloy

Fuel-cladding bonding

Model materials

Diffusion couple
G R A P H I C A L A B S T R A C T

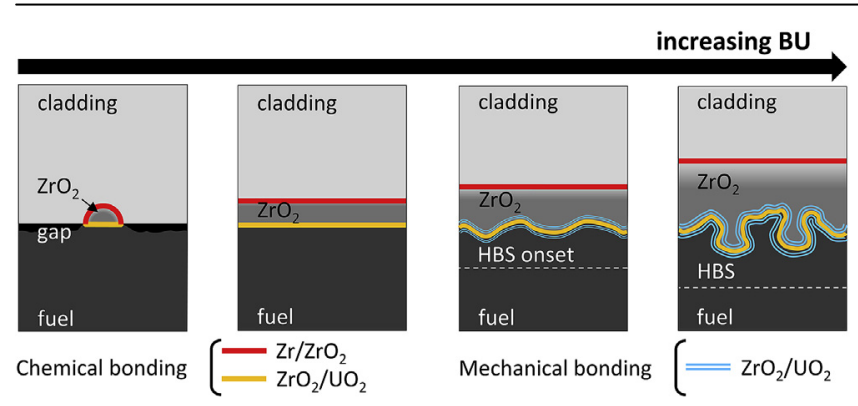

\section{Introduction}

In Pressurized Water Reactors (PWRs) the fuel rod comprises a stack of uranium dioxide pellets contained within a zirconium alloy

\footnotetext{
* Corresponding author. CIRIMAT-ENSIACET, UMR CNRS 5085, 31030, Toulouse, France.

E-mail address: clement.ciszak@ensiacet.fr (C. Ciszak).
}

sheath [1]. During in-reactor operation, radiation effects induce dimensional changes to the constitutive elements of the fuel rod. Within the fuel pellets, the gaseous (mainly $\mathrm{Xe}$ and $\mathrm{Kr}$ ) and socalled "solid" fission products (FP) produce a progressive swelling of the nuclear ceramic. This microstructural change, along with fuel differential thermal expansion leads to an expansion of each fuel pellet. On the other hand, the cladding is subjected to what is known as "creep-down", due to the combined effect of radiation and the external pressure induced by the primary coolant. Both 
phenomena (fuel expansion and creep-down) lead to a progressive reduction in the fuel cladding gap and eventually, a contact is established between the fuel and the cladding. From this point, a fuel-cladding bonding layer is formed that maintains a contact between the two. Moreover, depending on the amount and the strength of the fuel-cladding bonding, local thermal and mechanical properties of the fuel rod can be noticeably affected. Thus, evolution of the fuel-cladding bonding appears as an important parameter that must not be neglected for the description of the pellet-cladding interaction (PCI). For this purpose, the ALCYONE code (a fuel performance code for PWR developed by the CEA within the PLEIADES fuel performance software environment [2]) currently takes into account an increasing pellet-cladding friction coefficient as a function of burnup [3] in the PCI description. However, it does not really account of the effective role of the bonding layer in the fuel-cladding bonding and its evolution over time. In the literature, only a few papers [4-16] are devoted to the nature of this bonding layer. However, none of them offers a description of the role of this interfacial layer in the fuel-cladding bonding.

This paper addresses the issue of the nature and the evolution of this bonding. The present work is in continuity of previous characterizations performed on the fuel-cladding interface of a specimen of a $58.7 \mathrm{GWd} \cdot \mathrm{t}_{\mathrm{U}}^{-1}$ average burn-up [16]. This previous study has shown that, the fuel-cladding bonding layer was exclusively composed of a stratification of $\mathrm{ZrO}_{2}$ phases (monoclinic and tetragonals). In addition, the FP gradients observed along the $\mathrm{ZrO}_{2}$ thickness were supposed to stabilize tetragonal $\mathrm{ZrO}_{2}$ (by radiation damage and chemical doping effects) in the first micrometers close to the fuel $\mid \mathrm{ZrO}_{2}$ interface. Similar results were also obtained on a sample of $35.3 \mathrm{GWd} . \mathrm{t}_{\mathrm{U}}^{-1}$ average burn-up [17]. In each case, no kind of FP based interphase was detected. Although Cs-rich interphases were reported in Refs. [4-9,14], Van den Berghe et al. [14] have associated the presence of such Cs-rich compounds to high-duty fuels essentially. Indeed, their irradiation at high temperature during their entire stay in reactor would enable Cs to diffuse along thermal gradients up to the fuel-cladding interface.

In order to bring some new detailed experimental elements that would help to improve the current description of the fuel-cladding bonding used for its modelling, examinations of fuel-cladding bonding layers were performed by optical microscopy (OM) and scanning electron microscopy (SEM) on PWR fuel rods samples with $35.3 \mathrm{GWd} \cdot \mathrm{t}_{U}^{-1}$ and $64.5 \mathrm{GWd} \cdot \mathrm{t}_{U}^{-1}$. In the aim of having a better understanding of this bonding layer, a laboratory experiment was also performed on a model system consisting of annealed fuel and cladding materials. The results of both observations are compared and discussed to identify the bonding mechanisms and interpret its evolution as a function of the burn-up.

\section{Experimental}

\subsection{Spent nuclear fuel materials}

The spent nuclear fuel samples investigated in this study are PWR fuel rod samples of $35.3 \mathrm{GWd} \cdot \mathrm{t}_{\mathrm{U}}^{-1}$ and $64.5 \mathrm{GWd} . \mathrm{t}_{\mathrm{U}}^{-1}$ average burn-ups. They are composed of a standard $\mathrm{UO}_{2}$ enriched fuel ( $4.5 \mathrm{wt} \%{ }^{235} \mathrm{U}$ ) and a low tin content Zircaloy-4 cladding (1.3 wt \% $\mathrm{Sn})$. Composition of the low tin Zircaloy-4 cladding material is given in Table 1. All characterizations performed on these samples

Table 1

Average chemical composition of the low tin content Zircaloy-4 cladding material.

\begin{tabular}{llllll}
\hline Element & $\mathrm{Zr}$ & $\mathrm{Sn}$ & $\mathrm{Fe}$ & $\mathrm{Cr}$ & $\mathrm{O}$ \\
\hline Content (wt. \%) & Bal. & 1.3 & 0.2 & 0.1 & 0.12 \\
\hline
\end{tabular}

were done on radial cross sections. To prepare the cross-sections, each sample was cut and mirror polished. They were then cleaned with ethanol. All samples preparation steps, i.e. cutting, epoxy impregnation/embedding and polishing, were conducted in hot cells at the LECA-STAR hot laboratory (CEA Cadarache, France).

\subsection{Experiments on model materials}

In order to go further than was possible in the hot cell facility, within the framework of separate effects studies, a complementary study was performed using model materials to recreate the fuelcladding bonding. Experimental conditions relative to the interdiffusion annealing, especially the temperature, the contact pressure and the gaseous atmosphere, were chosen to mimic in-reactor conditions as closely as possible, but in the absence of radiations. The diffusion couples were composed of alternating Zircaloy- 4 and uranium dioxide disks with flat interfaces. These materials are described in the following sections.

\subsubsection{Model materials}

The diffusion couple was composed of Zircaloy- 4 disks $(8.2 \mathrm{~mm}$ in diameter and about $3 \mathrm{~mm}$ thick) placed on both sides of two depleted uranium dioxide disks $\left(0.3 \mathrm{wt} \%{ }^{235} \mathrm{U}, 8.2 \mathrm{~mm}\right.$ in diameter and about $1 \mathrm{~mm}$ thick). One uranium dioxide disk was stoichiometric $\left(\mathrm{UO}_{2.00}\right)$, while the other was hyper-stoichiometric $\left(\mathrm{UO}_{2.10}\right)$. The whole stack was enclosed in a dedicated Zircaloy container. Prior to their stacking in the Zircaloy container, each disk was mirror polished in order to provide the best possible interfaces. Materials were then cleaned with ethanol.

Hyper-stoichiometric uranium dioxide $\left(\mathrm{UO}_{2.10}\right.$ in our case) was used to verify the effect of excess of oxygen in $\mathrm{UO}_{2}$ upon the solidstate oxidation of zirconium. Indeed, based on Mallett et al. results [18], the excess of oxygen in $\mathrm{UO}_{2}$ was highly suspected to be responsible for oxidation of the cladding inner side in PWR fuel rods.

Oxidation of $\mathrm{UO}_{2}$ samples was performed at the $\mathrm{UO}_{2}$ laboratory (CEA Cadarache).

Controlled oxidation of $\mathrm{UO}_{2}$ samples to $\mathrm{UO}_{2.10}$ was carried out under carefully monitored oxygen partial pressures and temperatures in an alumina furnace equipped at the input and output with two yttria doped zirconia oxygen sensors. The oxygen partial pressure was controlled by the following gas-phase reaction (Eq. (1)):

$$
\mathrm{CO}_{2}+\mathrm{O}_{2} \leftrightarrow \mathrm{CO}+\frac{1}{2} \mathrm{O}_{2}
$$

A mixture of argon with $10 \% \mathrm{CO}_{2}$ was used as carrier gas. The $\mathrm{CO}_{2} / \mathrm{CO}$ equilibrium was set up using a solid electrolyte zirconia oxygen pump $[19,20]$ that can be used to extract small quantities of oxygen in the gas phase upstream from the sample. All samples were equilibrated at around $1100{ }^{\circ} \mathrm{C}$. The oxygen content of each sample changed as it equilibrated with the surrounding gas mixture. Oxidizing conditions were maintained for $20 \mathrm{~h}$ in order to allow time for oxidation to be complete thus guaranteeing that samples were homogeneous. At the end of the equilibration process, the samples which were mounted on a mobile sample holder were effectively quenched by extracting the sample holder into the cold portion of the furnace, thus freezing their oxygen content, which is finally redistributed in a $\mathrm{U}_{4} \mathrm{O}_{9}$ and $\mathrm{UO}_{2}$ two-phase mixture. The estimated deviation-from-stoichiometry corresponding to the annealing conditions, i.e. temperature and measured oxygen partial pressure was 0.10 . These estimates are based upon annealing conditions and our knowledge of the chemical potential of oxygen for $\mathrm{UO}_{2+\mathrm{x}}$, but weight gain measurements were also carried out. 


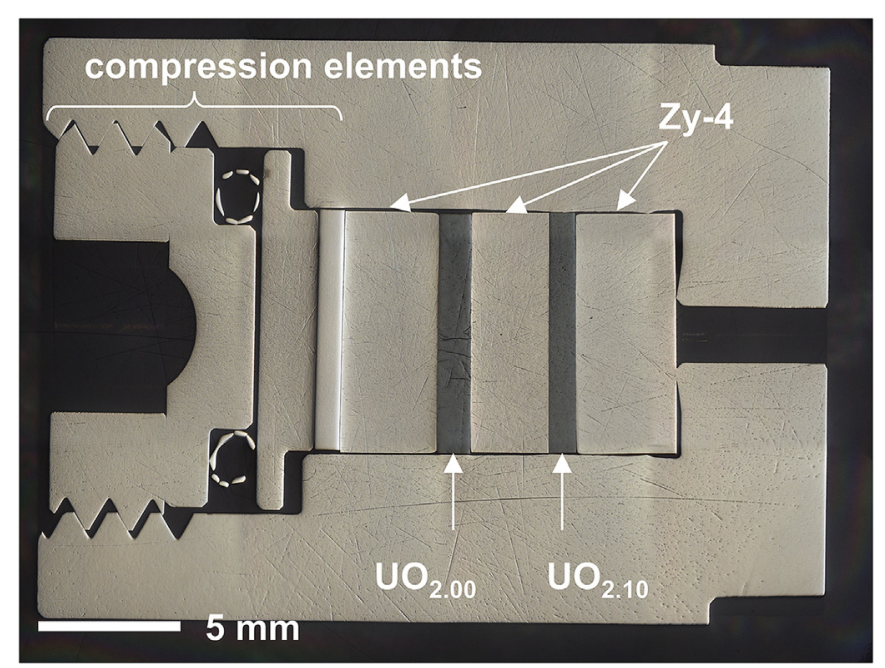

Fig. 1. Optical macrograph of an axial cross section of the Zircaloy container loaded with the diffusion couples stack.

Thus, our estimates were confirmed by weight gain measurements, with an initial weight of $2.248 \mathrm{~g}$ and an associated weight gain of $1.410^{-2} \mathrm{~g}$ after annealing. Aware that a 0.10 deviation-fromstoichiometry seems noticeably higher than the 0.005 deviationfrom-stoichiometry reported for irradiated fuels [21-23], such deviation-from-stoichiometry was nevertheless voluntary kept to heighten the Zircaloy/uranium dioxide reactivity.

\subsubsection{Sample holder and experimental conditions}

Fig. 1 presents an optical micrograph of an axial cross section of the Zircaloy container loaded with the two diffusion couples.

In order to promote solid state oxidation at the $\mathrm{Zr} \mid \mathrm{UO}_{2}$ interface and limit that of the cladding constituents via the gas phase, annealing was performed in an airtight tubular furnace using a constant pure argon gas-flow. Prior to entering the annealing device, the gas was made to flow through a solid state electrochemical oxygen pump similar to the one alluded to in the previous paragraph. This has the effect of reducing the oxygen content of the gas from between 1 and $10 \mathrm{ppm}$ to a value measured using an oxygen probe of $10^{-14} \mathrm{ppm}$. However, it is difficult to attribute a physical meaning to this latter value since no gas phase equilibrium is set up in that case.

Concerning the other experimental parameters, the annealing temperature was set to $400 \pm 3{ }^{\circ} \mathrm{C}$, according to the estimates of the fuel-cladding interfacial temperature under normal PWR operating conditions [24,25]. In a similar approach, a compressive strength of about $10 \pm 0.2 \mathrm{MPa}$ was applied on the diffusion couple stack. This value corresponds to the highest level of fuel-cladding contact pressure reached under normal PWR operating conditions, according to the evolution of the fuel/cladding contact pressure evolution with burnup estimated by the ALCYONE code presented in Fig. 2.

Application of this compressive stress on the diffusion couple stack was achieved through a specifically designed torus shaped spring, which appears as two rings on the left hand side of Fig. 1.

\subsection{Characterization tools}

\subsubsection{Characterization tools used on spent nuclear fuel materials}

Optical observations of the spent nuclear fuel sample were performed using a shielded optical microscope (Optique Peter, Lyon, France) set up in a hot cell at the LECA-STAR hot laboratory.

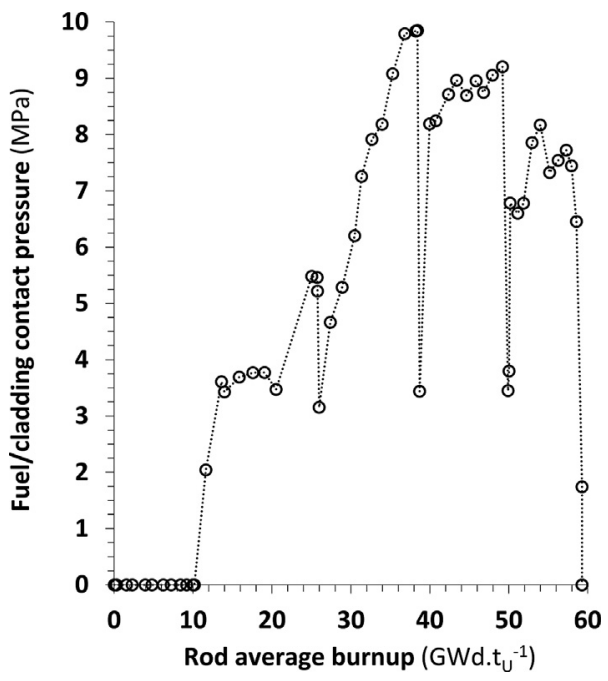

Fig. 2. ALCYONE code estimation of the evolution of the fuel/cladding contact pressure as a function of the fuel rod average burnup.

SEM observations of the spent nuclear fuel sample were performed using a nuclearized Zeiss Auriga 40 FEG-SEM, set up in a hot cell and connected to a glove box at the LECA STAR hot laboratory.

\subsubsection{Characterization tools used on model materials}

Optical observations of model materials were performed using an Olympus DSX100 opto-numeric microscope.

SEM observations and Energy Dispersive Spectroscopy (EDS) measurements on model materials were performed using a FEI Nova NanoSEM 450 available at the $\mathrm{UO}_{2}$ Laboratory (CEA Cadarache, France), equipped with a $20 \mathrm{~mm}^{2}$ Oxford SDD X-Max detector. EDS analyses were done at $20 \mathrm{kV}$.

Thin foils were extracted and thinned using a FEI Helios 600 NanoLab Focused Ion Beam (FIB) available at CP2M (Aix-Marseille University, France). The region of interest was first protected by a Pt deposit using the FIB. The bulk sample was then milled using the FIB to obtain a thin sample of approximately $2 \mu \mathrm{m}$ thick, $10 \mu \mathrm{m}$ length and $5 \mu \mathrm{m}$ height.

Transmission Electron Microscopy (TEM) observations were performed using a FEI Tecnaï G2 TEM at CP2M. This TEM is equipped with a CCD TVIPS $1 \mathrm{k} \times 1 \mathrm{k}$ camera and an $80 \mathrm{~mm}^{2}$ Oxford SDD X-Max detector for EDS measurements. Observations were done at $200 \mathrm{kV}$. Measurements of diffraction patterns and highresolution micrographs were performed with the Olympus Soft Imaging System pro 5.0 software.

\section{Results}

\subsection{Results related to the spent nuclear fuel samples}

This section presents the results obtained on the moderate and high burn-ups spent nuclear fuel samples.

\subsubsection{Sample of $35.3 \mathrm{GWd} \cdot \mathrm{t}_{U}^{-1}$ moderate burnup}

Fig. 3 presents an optical micrograph of the fuel-cladding interface of the $35.3 \mathrm{GWd} \cdot \mathrm{t}_{\mathrm{U}}^{-1}$ sample. Each compound can clearly be identified here, as well as the interfaces. The black area between the zirconia islet and the fuel corresponds to the re-opening of the initial pellet-cladding gap during the fuel rod cooling. At this moderate burnup, internal zirconia consists of islets about $8 \mu \mathrm{m}$ thick, whose widths are variable, depending on the contact surfaces between fuel and cladding during reactor operation. Re-opening of 


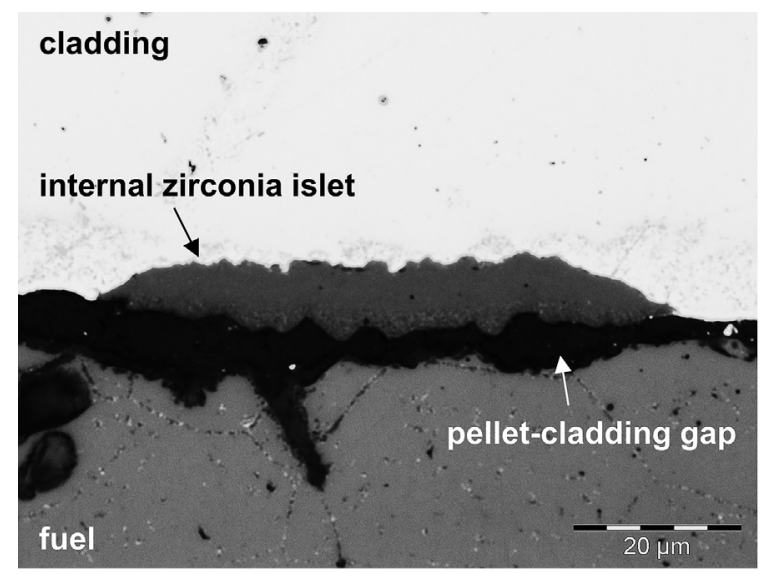

Fig. 3. Optical micrograph of the fuel|cladding interface of the $35.3 \mathrm{GWd} \cdot \mathrm{t}_{\mathrm{U}}^{-1}$ sample showing an islet of internal zirconia.

the pellet-cladding gap and the absence of fuel fragments stuck to the cladding are indications of the absence of strong fuel-cladding bonding.

However, depending on the observed zone, these conclusions may be slightly different. Fig. 4 presents an optical micrograph of another zone of the fuel-cladding interface of the $35.3 \mathrm{GWd} \cdot \mathrm{t}_{\mathrm{U}}^{-1}$ sample. Here, a detailed observation of the $\mathrm{ZrO}_{2} \mid \mathrm{UO}_{2}$ interface reveals the presence of a fuel fragment that have remained bonded to the surface of the zirconia layer (indicated by white arrows in Fig. 4). Cracks can also be observed in the fuel close to these bonded zones (indicated by white dashed lines).

To go further in the investigation, similar observations were performed by SEM.

Fig. 5 presents an electron micrograph in backscattered electron (BSE) contrast of the fuel|cladding interface of the $35.3 \mathrm{GWd} \cdot \mathrm{t}_{\mathrm{U}}^{-1}$ sample centered on $\mathrm{ZrO}_{2}-\mathrm{UO}_{2}$ interfacial bonding areas. As previously mentioned, the two black areas represent voids, which are due to the re-opening of the initial pellet-cladding gap during fuel rod cooling. The increasing grain size that can be observed along the zirconia layer thickness was reported to be similar to those previously observed in our team on a $58.7 \mathrm{GWd} . \mathrm{t}_{\mathrm{U}}^{-1}$ sample [16,17], as the evolution of the associated crystalline structure [16,17].

Moreover, according to this electron micrograph, the $\mathrm{t}-\mathrm{ZrO}_{2} \mid \mathrm{UO}_{2}$

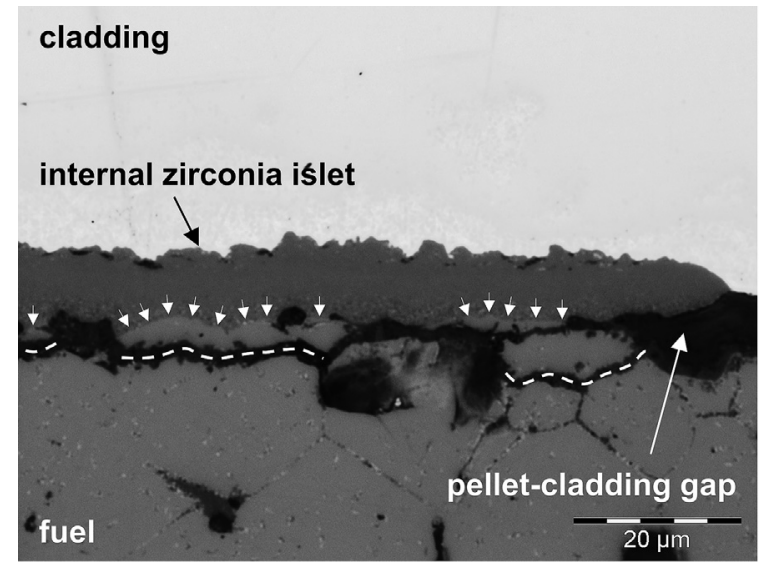

Fig. 4. Optical micrograph of the fuel-cladding interface of the $35.3 \mathrm{GWd} \cdot \mathrm{t}_{\mathrm{U}}^{-1}$ sample showing pieces of fuel locally bonded to an internal zirconia islet. The small white arrows indicate the bonded zirconia-fuel zones. Dashed lines indicate the location of cracks in the adjacent pellet. interface appears relatively straight, with a direct physical transition from one material to the other. Furthermore, as is observed in Fig. 5, a large crack (partially filled by grinding residues) can be seen in the fuel (on the right hand side of the micrograph), close to the $t$ $\mathrm{ZrO}_{2} \mid \mathrm{UO}_{2}$ interfacial zones.

These observations demonstrate that the internal zirconia layer is essentially responsible for bonding that occurs between the fuel and the cladding.

\subsubsection{Sample of $64.5 \mathrm{GWd} . \mathrm{t}^{-1}$ high burnup}

Fig. 6 presents an optical micrograph of the fuel|cladding interface of a $64.5 \mathrm{GWd} \cdot \mathrm{t}_{\mathrm{U}}^{-1}$ sample. In this figure, the fuel at the rim of the pellet is restructured into high burn-up structure (HBS), where the initial $\mathrm{UO}_{2}$ grains are subdivided into much smaller grains, most of the fission gases have formed micrometric intergranular bubbles (dark spots in the micrograph) and many metallic fission product precipitates have formed (bright spots in the micrograph) [26].

At this stage, the initial pellet-cladding gap is no longer visible, suggesting a fully achieved fuel-cladding bonding. A continuous interfacial zirconia layer (whose location and thickness is estimated by the white dashed double arrows) has formed between fuel and cladding. Nevertheless, if the oxidation front, that is $\mathrm{Zy}-4 \mid \mathrm{ZrO}_{2}$ interface, is clearly identified, it is rather difficult to distinguish the $\mathrm{ZrO}_{2} \mid \mathrm{UO}_{2}$ interface.

Fig. 7 presents an optical micrograph of the same zone after a chemical etching in $\mathrm{H}_{2} \mathrm{SO}_{4}-\mathrm{H}_{2} \mathrm{O}_{2}$ aqueous solution of the fuel. This fuel selective chemical etching allows the $\mathrm{ZrO}_{2} \mid \mathrm{UO}_{2}$ interface to be easier identified. The specific $\mathrm{ZrO}_{2} \mid \mathrm{UO}_{2}$ interface thereby appears to be highly wavy shaped, exhibiting an interpenetration of both materials, obviously achieved through the development of interfacial circumvolutions.

Fig. 8 presents a SEM micrograph of the fuel side surface of the internal zirconia of the $64.5 \mathrm{GWd} \cdot \mathrm{t}_{\mathrm{U}}^{-1}$ sample in secondary electron (SE) contrast, after the chemical dissolution of the fuel.

Here a complete representation of the highly wavy shape of the zirconia at its interface with the fuel can be seen. This particular interfacial morphology appears to be composed of several "worms" like zirconia and fuel circumvolutions interlocked across the three dimensions.

In the following, we describe model experiments using model materials designed to recreate a fuel-cladding bonded situation, through an interfacial zirconia layer.

\subsection{Results related to experiments on model materials}

This section presents the results obtained in the separate effects experiment using the diffusion couple made of un-irradiated model materials.

\subsubsection{Optical microscopy}

Fig. 9 presents an optical micrograph of a $\mathrm{Zy}-4 \mid \mathrm{UO}_{2.00}$ interface, for a model system annealed for $250 \mathrm{~h}$ at $400^{\circ} \mathrm{C}$, under a purified $\mathrm{Ar}$ atmosphere and a compressive load of about $10 \mathrm{MPa}$. Here, no sign of $\mathrm{Zr}$ oxidation can be seen, in agreement with Mallett et al. [18] results obtained on a $\mathrm{Zr}-\mathrm{UO}_{2.00}$ stacked diffusion couple annealed for $13872 \mathrm{~h}$ at $399^{\circ} \mathrm{C}$ under an isostatic pressure of 345 bar of He.

Fig. 10 presents an optical micrograph of a $\mathrm{Zy}-4 \mid \mathrm{UO}_{2.10}$ interface, treated under identical conditions. In that case, the $\mathrm{Zy}-4 \mid \mathrm{UO}_{2.10}$ interface exhibits some irregularities associated with the presence of dark areas similar to $\mathrm{ZrO}_{2}$ islets in irradiated fuels (identified by white arrows in Fig. 10). The nature of these areas has been checked by EDS in a SEM (see section 3.2.2). 


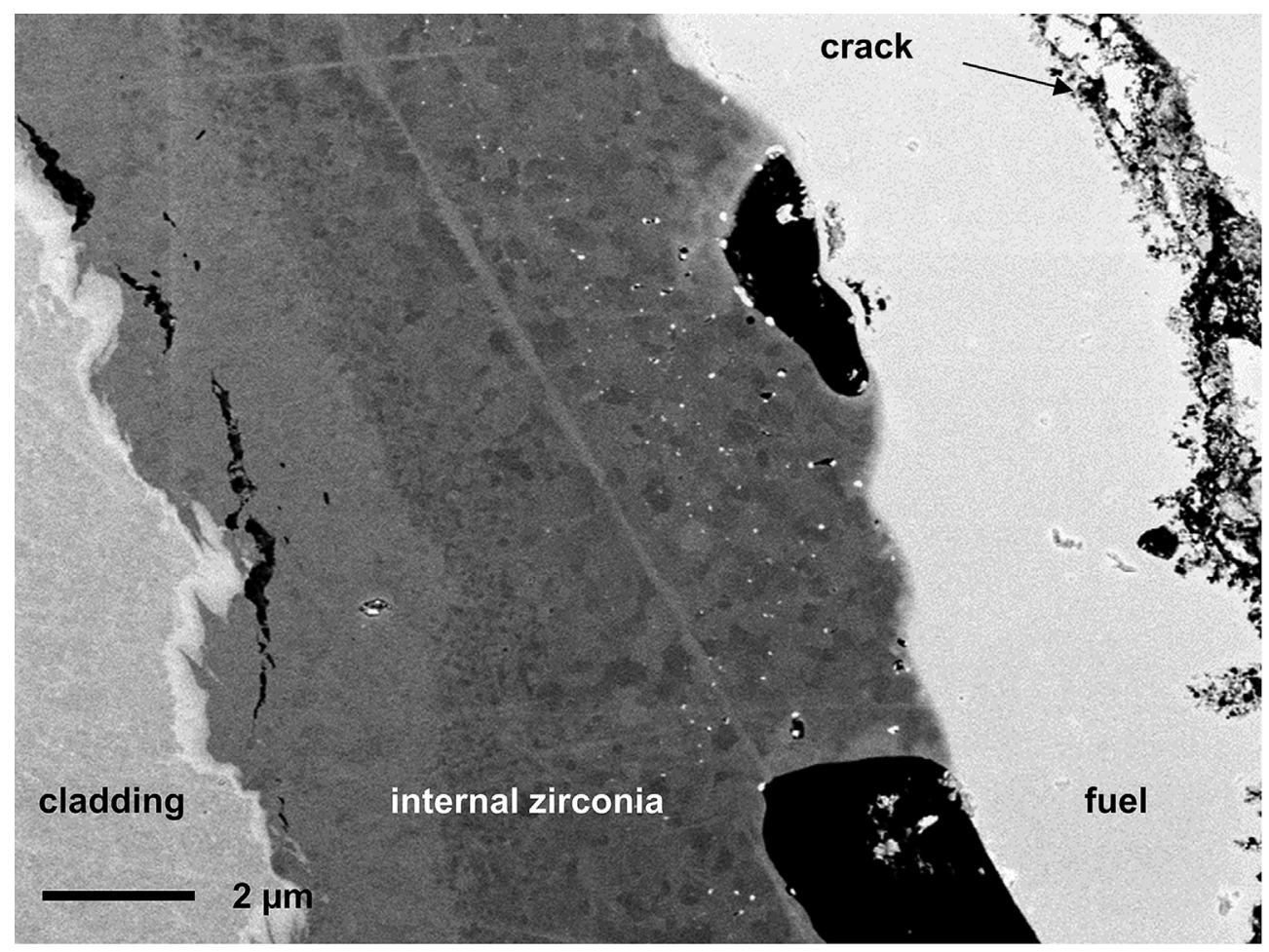

Fig. 5. SEM micrograph of the fuel $\mid$ cladding interface of the $35.3 \mathrm{GWd} \cdot \mathrm{t}_{\mathrm{U}}^{-1}$ sample in $\mathrm{BSE}$ contrast, centered on a $\mathrm{ZrO}_{2} \mid \mathrm{UO}_{2}$ bonded zone.

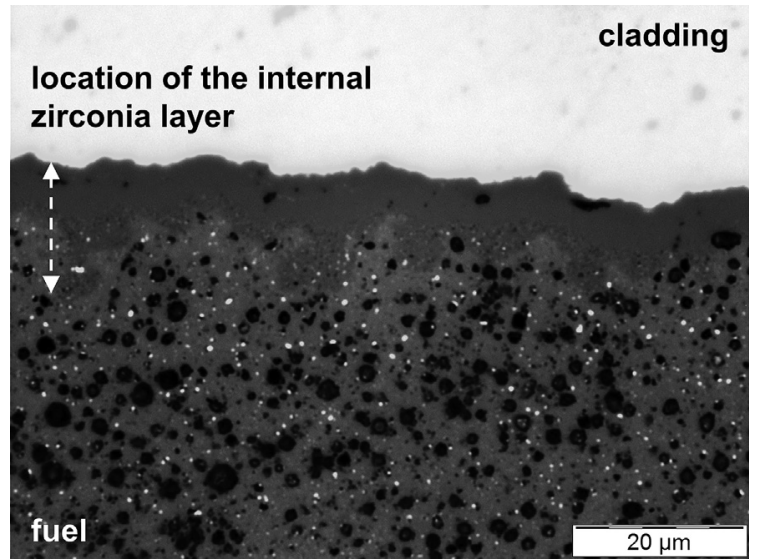

Fig. 6. Optical micrograph of the fuel|cladding interface of a $64.5 \mathrm{GWd} \cdot \mathrm{t}_{\mathrm{U}}^{-1}$ sample.

\subsubsection{SEM observations}

SEM analyses were performed on the thickest dark area identified in Fig. 10 (the first from the top). Fig. 11 presents an electron micrograph of this precipitate in BSE contrast.

The dark contrast observed at the precipitate location tends to indicate that this precipitate could be $\mathrm{ZrO}_{2}$. This assumption was supported by the elementary composition of approximately 39 at.\% of $\mathrm{Zr}$ and 61 at.\% of $\mathrm{O}$ obtained by EDS analyses at the precipitate location, and confirmed by Raman spectroscopy [17].

The contrast observed inside the $\mathrm{UO}_{2.10}$ sample was attributed to $\mathrm{U}_{4} \mathrm{O}_{9}$ (light grey) and $\mathrm{UO}_{2}$ (dark grey) two-phase mixture after the Raman spectroscopy analyses [17].

According to the evolution of the $\mathrm{ZrO}_{2}$-islet $\mid \mathrm{UO}_{2}$ interfacial morphology observable in Fig. 11, the central portion of the $\mathrm{ZrO}_{2}$ islet would seem to be bonded to the $\mathrm{UO}_{2}$ neighboring grain and was therefore chosen for detailed analyses.

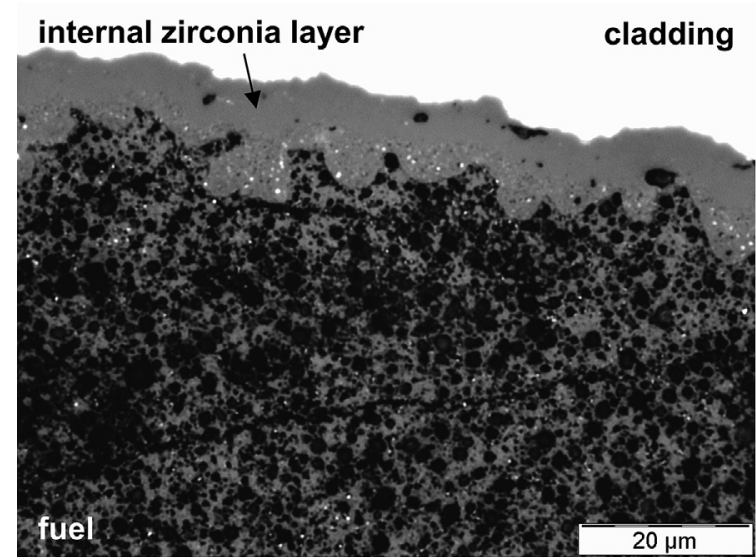

Fig. 7. Optical micrograph of the same area presented in Fig. 6, after a $\mathrm{H}_{2} \mathrm{SO}_{4}-\mathrm{H}_{2} \mathrm{O}_{2}$ chemical etching of the fuel.

\subsubsection{Detailed analysis of the $\mathrm{ZrO}_{2} \mid \mathrm{UO}_{2}$ interface by TEM}

In order to characterize the interface between the $\mathrm{ZrO}_{2}$ islet and $\mathrm{UO}_{2}$ with a greater level of detail, a detailed characterization was performed by TEM. Thus, a thin foil sample was extracted trough the $\mathrm{Zy}-4\left|\mathrm{ZrO}_{2}\right| \mathrm{UO}_{2}$ interfaces using a FIB. For clarity reasons, Fig. 12a presents a SEM micrograph, in SE contrast, of the extracted and welded (on a Cu TEM thin foil holder) thin sample before the final thinning step, and Fig. 12b shows a bright field image of this sample after its final thinning. Its thinnest zone thickness (just beneath the Pt protective coating) was estimated using Electron Energy Loss Spectroscopy (EELS) on average at $80 \mathrm{~nm}$. Moreover, it can be observed at this specific location on both Fig. 12a and b, that the top of the zirconia islet seems to be tightly bonded to the $\mathrm{UO}_{2}$ substrate. On the contrary, the bottom of the zirconia islet appears to be not bonded to $\mathrm{UO}_{2}$, with the presence of a gap between the two 


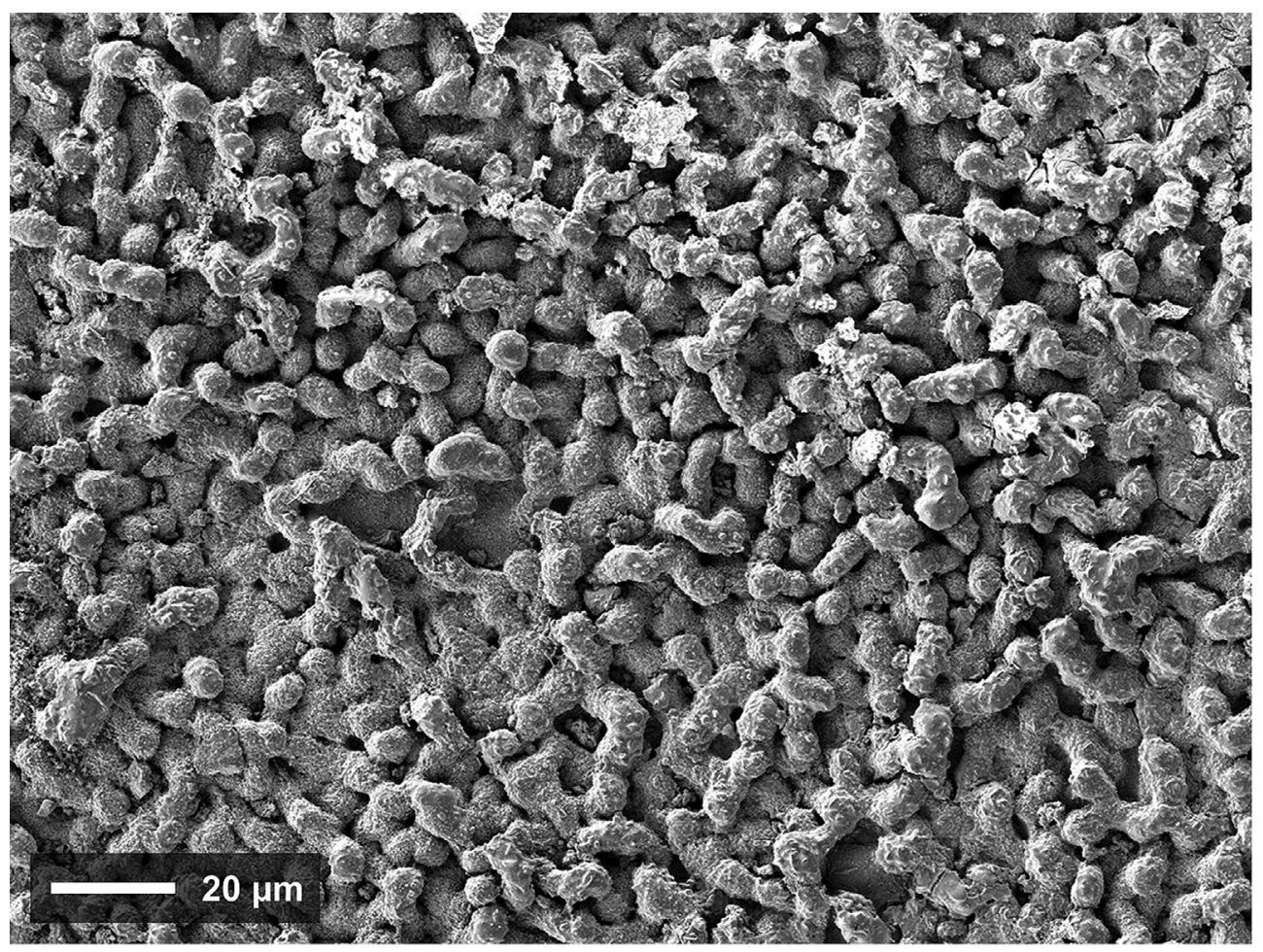

Fig. 8. SEM micrograph of the fuel side surface of the internal zirconia of the $64.5 \mathrm{GWd} . \mathrm{t}_{\mathrm{U}}^{-1}$ sample in SE contrast, after the chemical dissolution of the fuel.

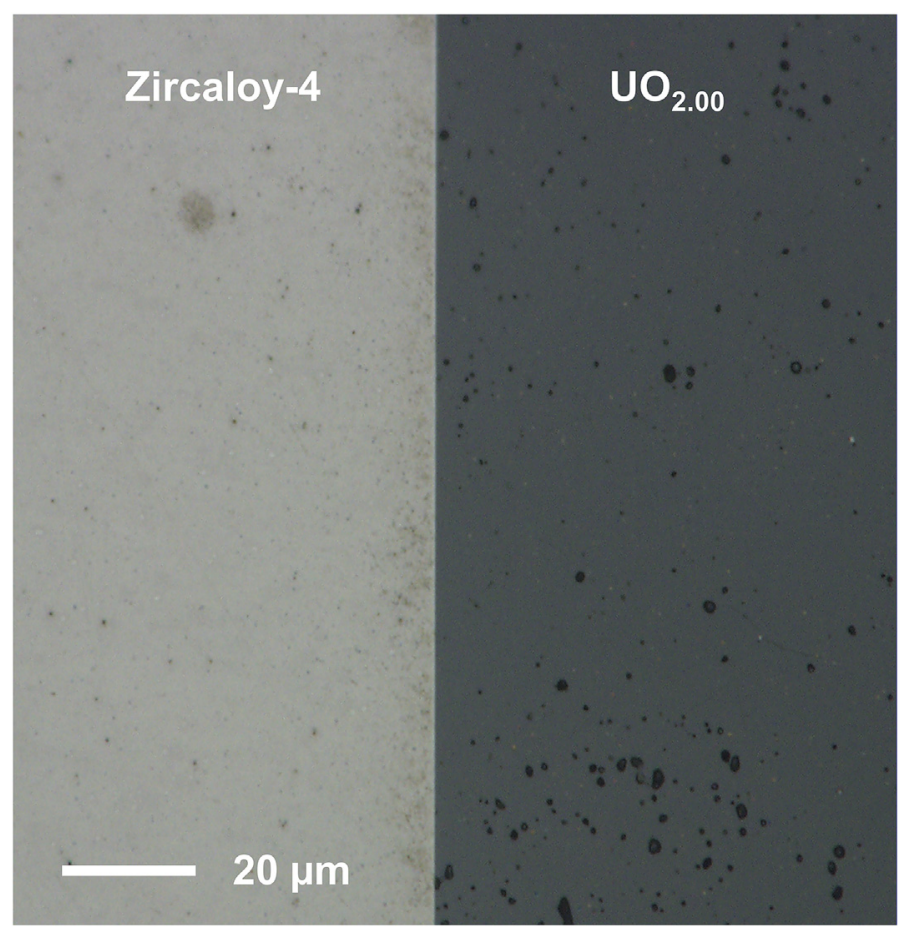

Fig. 9. Optical micrograph of a $\mathrm{Zy}-4 \mid \mathrm{UO}_{2.00}$ interface, annealed for $250 \mathrm{~h}$ at $400^{\circ} \mathrm{C}$, under an $\mathrm{Ar}$ atmosphere $\left(\mathrm{P}\left(\mathrm{O}_{2}\right)=10^{-21}\right.$ atm $)$.

materials, which would be likely from the cooling of the diffusion couple.

In order to investigate the elements distribution across the $\mathrm{ZrO}_{2} \mid \mathrm{UO}_{2}$ interface, EDS profiles were recorded in the thinnest zone of the sample from $\mathrm{ZrO}_{2}$ to $\mathrm{UO}_{2}$. Results are presented in Fig. 13.

According to the evolution of the EDS profiles, the sharp transition between $\mathrm{ZrO}_{2}$ and $\mathrm{UO}_{2}$ suggests that no other compound is present at the $\mathrm{ZrO}_{2} \mid \mathrm{UO}_{2}$ interface.

The crystalline structure of each compound was then verified/ determined by Selected Area Diffraction (SAD), performed on three zones corresponding to $\mathrm{Zy}-4, \mathrm{ZrO}_{2}$ and $\mathrm{UO}_{2}$. The obtained electron diffraction patterns, respectively noted $\mathrm{A}, \mathrm{B}$ and $\mathrm{C}$, are presented in 


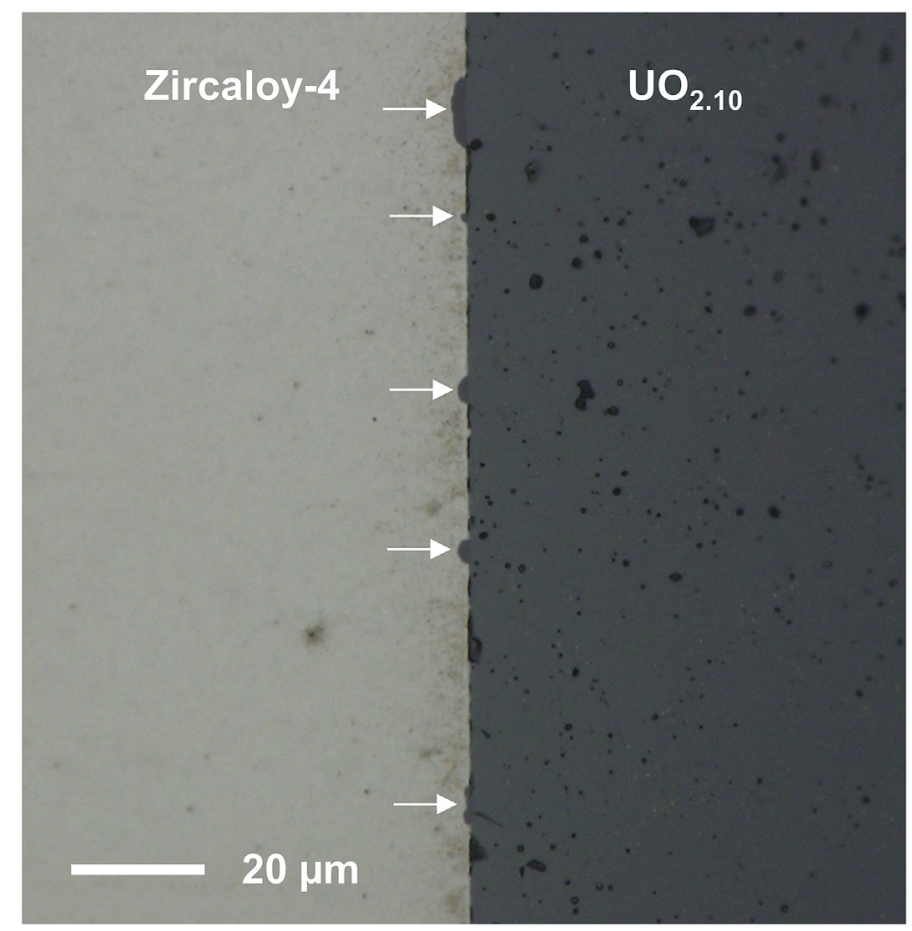

Fig. 10. Optical micrograph of a $\mathrm{Zy}-4 \mid \mathrm{UO}_{2.10}$ interface, annealed for $250 \mathrm{~h}$ at $400^{\circ} \mathrm{C}$, under an $\operatorname{Ar}$ atmosphere $\left(\mathrm{P}\left(\mathrm{O}_{2}\right)=10^{-21}\right.$ atm $)$.

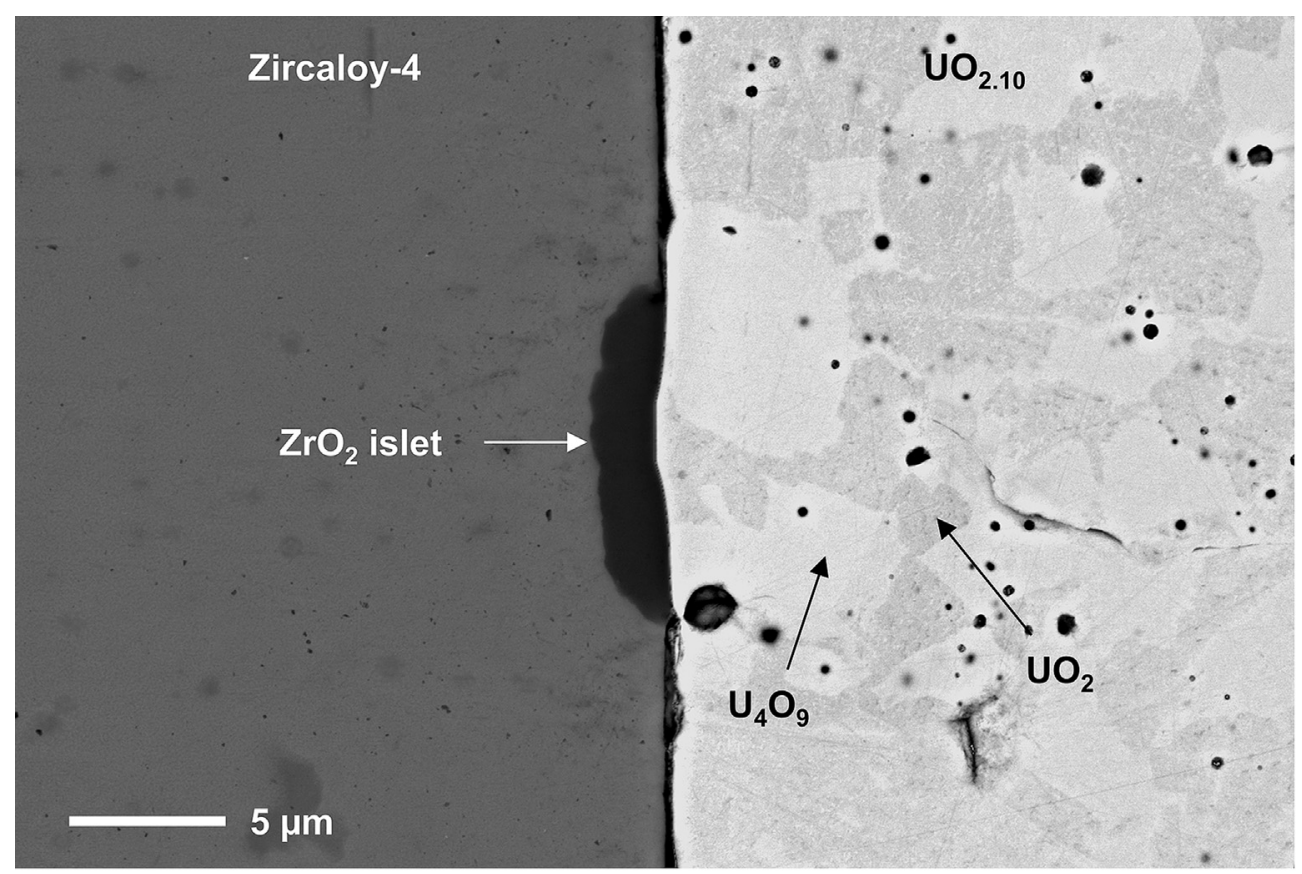

Fig. 11. SEM micrograph in BSE contrast of the thickest dark area observed in Fig. 10.

Fig. 14. Unsurprisingly, SAD confirms the hexagonal closed pack (hcp) structure of Zy-4 in zone A (ICDD 04-008-1477) and the face centered cubic (fcc) structure of $\mathrm{UO}_{2}$ in zone C (ICDD 00-041-1422). Finally, the SAD pattern obtained in zone $\mathrm{B}$, corresponding to the $\mathrm{ZrO}_{2}$ layer, shows the presence of monoclinic zirconia $\mathrm{m}-\mathrm{ZrO}_{2}$ (ICDD 00-037-1484), in agreement with the thermodynamic predictions. The discontinuous rings obtained in this case are characteristic of grains of submicron sizes. A complementary characterization performed by ASTAR (Automated crystal phase and orientation mapping in TEM by precession diffraction) [27], revealed that the zirconia islet would be composed of two distinct areas [17]. A first fine layer of equiaxed grains of 5-10 nm diameter would be at direct contact with $\mathrm{UO}_{2}$, followed by a large zone of columnar grains (perpendicularly to the $\mathrm{Zr} \mid \mathrm{ZrO}_{2}$ interface) of approximately $200 \mathrm{~nm}$ length and 50-100 $\mathrm{nm}$ in width [17].

The thinnest zone of the $\mathrm{m}-\mathrm{ZrO}_{2} \mid \mathrm{UO}_{2}$ interface was finally 

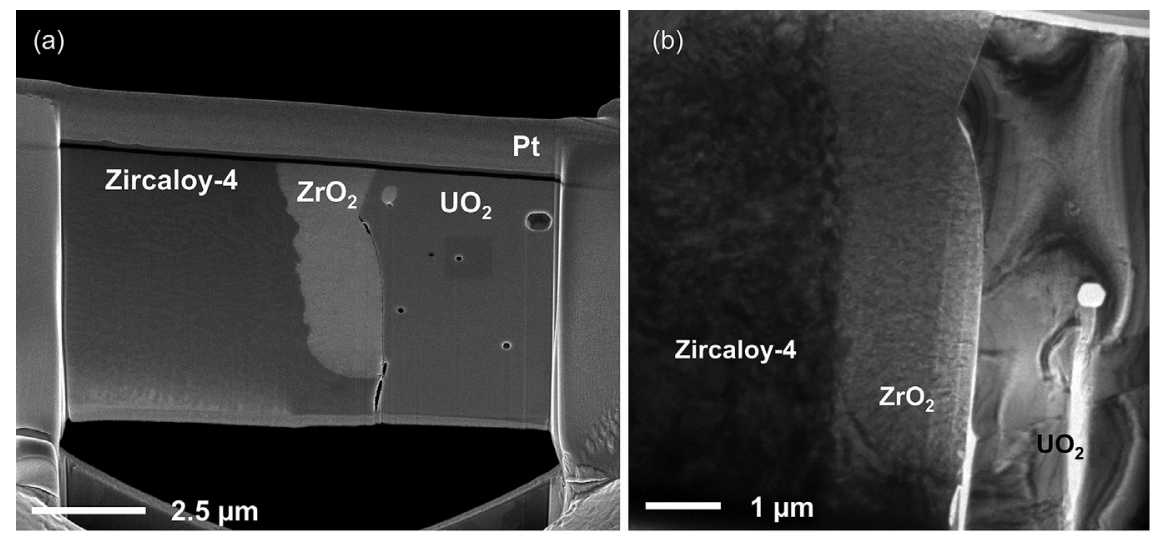

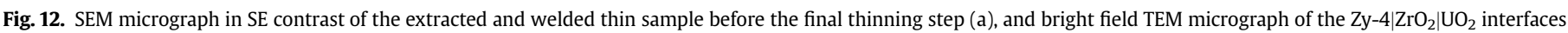
(b).

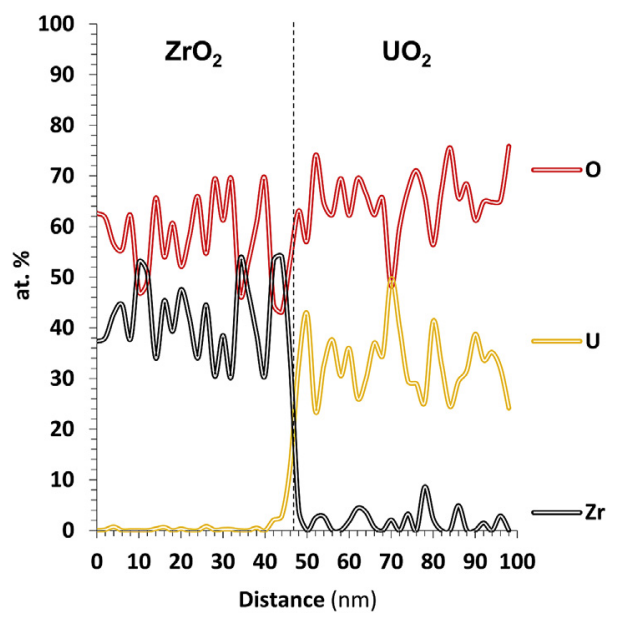

Fig. 13. Evolution of the $\mathrm{Zr}, \mathrm{U}$ and $\mathrm{O}$ TEM-EDS profiles across the $\mathrm{ZrO}_{2} \mid \mathrm{UO}_{2}$ interface.

observed at high magnification, providing a high-resolution micrograph of this interface. This micrograph is presented in Fig. 15. In agreement with EDS analyses, $\mathrm{m}-\mathrm{ZrO}_{2}$ and $\mathrm{UO}_{2}$ appear to be directly in contact with each other, without any interphase. Furthermore, direct junctions between the two oxide lattices are clearly observed. An alignment of some of crystalline planes of m$\mathrm{ZrO}_{2}$ and $\mathrm{UO}_{2}$ can even locally be seen, evidencing the presence of at least one coherent and/or semicoherent interface between both compounds. For each compound, comparison of the measured inter-planar distances of the aligned planes, respectively $3.1 \AA$ and $3.2 \AA$ for $\mathrm{m}-\mathrm{ZrO}_{2}$ and $\mathrm{UO}_{2}$, with theoretical inter-reticular distances shows that the (111) planes family of $\mathrm{m}-\mathrm{ZrO}_{2}(\mathrm{~d}=3.1647 \AA)$ and the (111) planes family of $\mathrm{UO}_{2}(\mathrm{~d}=3.1530 \AA)$ are involved in the observed atomic plane alignment.

\section{Discussion}

According to the results obtained on PWR fuel rod samples, the internal zirconia layer that develops at the fuel-cladding interface plays a crucial role in the fuel to cladding bonding. This study mainly focuses on the role of this interfacial zirconia layer in the fuel-cladding bonding phenomenon, and the evolution of this bonding with burnup. Thus, the different possible origins and the evolution with burnup of the fuel-cladding bonding are discussed in the following sections.

\subsection{General hypotheses on the origin of the fuel-cladding bonding}

According to the literature, many phenomena can lead to the bonding of two materials. Among them, physical, chemical and mechanical principles can be mainly cited $[28,29]$. Physical bonding are essentially due to the development of electrostatic bonds between the surfaces of the materials, such as van der Waals or hydrogen bonds $[28,29]$, which are considered as relatively low energy and then weak bonds [30]. By contrast, chemical bonding are classically considered as high energy and then strong bonding [30]. Depending on the nature of the materials, chemical bonds can be of a metallic, covalent and iono-covalent nature [29]. Finally, according to McBain's theory [31], bonding can also have a mechanical origin, achieved through the physical anchorage of two materials.

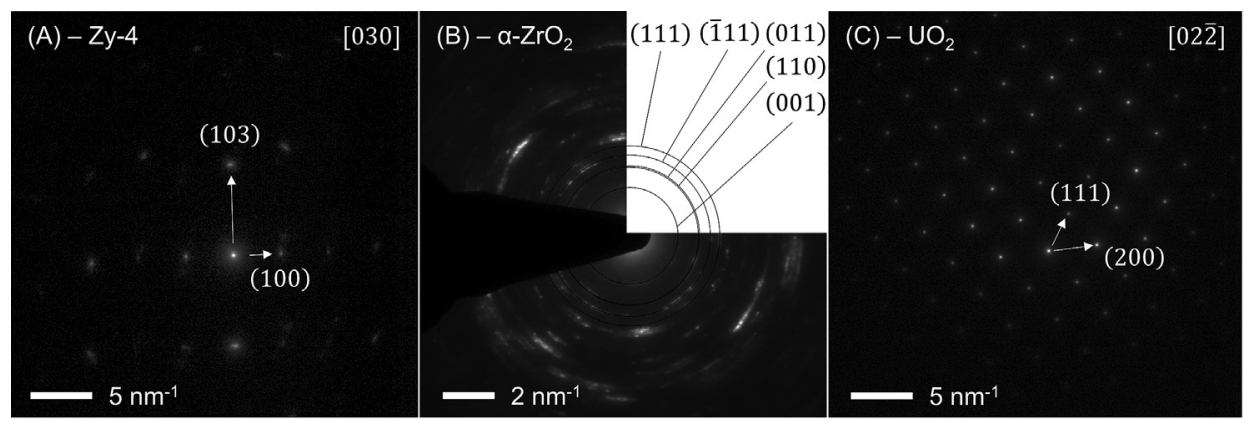

Fig. 14. Electron diffraction patterns obtained on zones $\mathrm{A}(\mathrm{Zy}-4), \mathrm{B}\left(\mathrm{ZrO}_{2}\right)$ and $\mathrm{C}\left(\mathrm{UO}_{2}\right)$. 


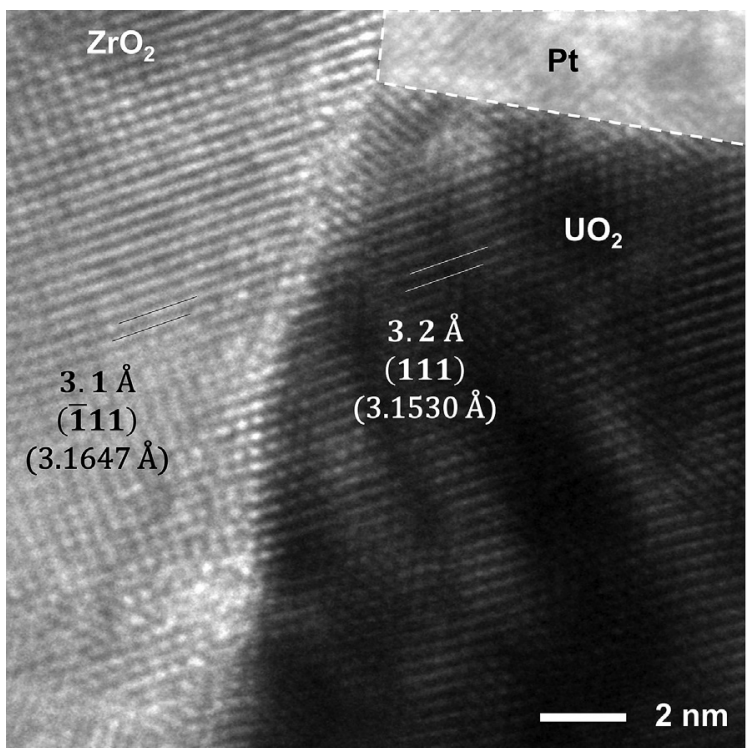

Fig. 15. High-resolution TEM micrograph of the $\mathrm{m}-\mathrm{ZrO}_{2} \mid \mathrm{UO}_{2}$ interface.

In the case of the fuel-cladding bonding, three different compounds are involved in the bounding: the fuel, the zirconia layer and the cladding, forming two distinct interfaces: the Zircaloy$4 \mid \mathrm{ZrO}_{2}$ interface and the $\mathrm{ZrO}_{2} \mid \mathrm{UO}_{2}$ interface. Therefore, the overall strong fuel-cladding bonding actually comes from two contributions: a first strong bonding at the Zircaloy- $4 \mid \mathrm{ZrO}_{2}$ interface, and a second strong bonding at the $\mathrm{ZrO}_{2} \mid \mathrm{UO}_{2}$ interface. Thus, each interface must be investigated to explain the overall fuel/cladding bonding.

\subsection{Origin of the Zircaloy-4| $\mid \mathrm{ZrO}_{2}$ bonding}

As the internal zirconia layer develops by inward oxidation of the cladding, the oxide formed has necessarily local coherent and/ or semicoherent interfaces at the oxidation front with the metallic matrix from which it develops and is therefore intimately bonded to it. Thus, a strong bonding is achieved between the internal zirconia layer and the cladding through the chemical bonds established between the two compounds.

As mentioned above, a strong bond is also required on the other side of the internal $\mathrm{ZrO}_{2}$ layer, at the $\mathrm{ZrO}_{2} \mid \mathrm{UO}_{2}$ interface, to achieve a permanent fuel-cladding bonding.

\subsection{Origin of the $\mathrm{ZrO}_{2} \mid \mathrm{UO}_{2}$ bonding}

\subsubsection{Elements provided by the $35.3 \mathrm{GWd} \cdot \mathrm{t}_{U}^{-1}$ irradiated sample}

The origin of the adhesion of zirconia with fuel at the $\mathrm{t}-\mathrm{ZrO}_{2} \mid \mathrm{UO}_{2}$ interface, which are two initially independent materials, is not obvious. Observation on the $35.3 \mathrm{GWd} \cdot \mathrm{t}_{\mathrm{U}}^{-1}$ sample of a straight interface between $\mathrm{t}-\mathrm{ZrO}_{2}$ and $\mathrm{UO}_{2}$, suggests that the $\mathrm{t}-\mathrm{ZrO}_{2} \mid \mathrm{UO}_{2}$ bonding should be either of a physical or a chemical nature, according to the different theories of adhesion. This assumption is supported by the low difference in surface energy of both $\mathrm{UO}_{2}$ and $\mathrm{ZrO}_{2}$ (around $0.76 \pm 0.53 \mathrm{~J} \mathrm{~m}^{-2}$ [32] and $1.2 \mathrm{~J} \mathrm{~m}^{-2}[33,34]$ at $400{ }^{\circ} \mathrm{C}$ respectively), which promotes adhesion phenomena.

The geometrical shape of the cracks observed in the fuel close to the bonded zones suggests that they are located at fuel grain boundaries. This observation evidences that locally, there was a fuel to zirconia bonding strong enough to prevent a re-opening of the gap. Thus, presence of such cohesive failures inside the fuel, close to the $\mathrm{t}-\mathrm{ZrO}_{2} / \mathrm{UO}_{2}$ bonded zones, means that the $\mathrm{t}-\mathrm{ZrO}_{2} \mid \mathrm{UO}_{2}$ interfacial adhesion strength is at least stronger than the fuel cohesive strength. The bond at the origin of such a strong adhesion should consequently be of high energy, and at least higher than the cohesion energy of the irradiated fuel grain boundaries. According to the lower bonding energy of physical bonds than chemicals, the $\mathrm{t}-\mathrm{ZrO}_{2} / \mathrm{UO}_{2}$ bonding observed on the irradiated sample should probably be of a chemical nature. Furthermore, as $\mathrm{t}-\mathrm{ZrO}_{2}$ and $\mathrm{UO}_{2}$ are both oxides, metallic and covalent kinds of bond can be ruled out. Therefore, only iono-covalent bond would remain to explain this $\mathrm{t}-\mathrm{ZrO}_{2} \mid \mathrm{UO}_{2}$ strong bonding.

\subsubsection{Elements provided by the model material diffusion couple}

In order to confirm or overturn the previous hypothesis of ionocovalent bonds between $\mathrm{t}-\mathrm{ZrO}_{2}$ and $\mathrm{UO}_{2}$, that would be responsible of their bonding in irradiated fuel rods, a fuel-cladding bonded interface was recreated using model materials diffusion couple.

The five dark areas observed at the $\mathrm{Zy}-4 \mid \mathrm{UO}_{2.10}$ interface (Fig. 10), similar to $\mathrm{ZrO}_{2}$ islets in irradiated fuels, also appears to be similar to those observed as a continuous layer by Mallett et al. [18] on a $\mathrm{Zr}$ /hyper-stoichiometric $\mathrm{UO}_{2.10}$ diffusion couple, composed of a zirconium cylinder buried in a uranium dioxide powder and annealed for $18 \mathrm{~h}$ at $825^{\circ} \mathrm{C}$ in $\mathrm{Ar}$. It is important to mention that in our case, like in theirs, the analogous $\mathrm{Zr}$ /stoichiometric $\mathrm{UO}_{2.00}$ sample did not exhibit any precipitate at the $\mathrm{Zr} \mid \mathrm{UO}_{2}$ interface. Based on these observations, Mallett et al. [18] hypothesized this continuous layer to be a zirconium oxide layer whose formation would be linked to the excess of oxygen in the hyper-stoichiometric $\mathrm{UO}_{2.10}$. Our results are fully in agreement with this hypothesis, considering that the formation of $\mathrm{ZrO}_{2}$ on a $\mathrm{Zr}$ substrate only occurs in presence of hyper-stoichiometric $\mathrm{UO}_{2+\mathrm{x}}$. As oxidation kinetics are known to be thermally activated, the annealing temperature in the case of Mallett et al. [18], twice higher than ours would explain the formation of a continuous $\mathrm{ZrO}_{2}$ layer in their case and only $\mathrm{ZrO}_{2}$ islets in our case.

TEM characterizations of the interface between the $\mathrm{ZrO}_{2}$ islet and $\mathrm{UO}_{2}$ revealed the presence of a local $\mathrm{ZrO}_{2} \mid \mathrm{UO}_{2}$ bonding situation obtained after annealing of a $\mathrm{Zy}-4 / \mathrm{UO}_{2.10}$ model material diffusion couple. SAD measurements evidencing the presence of $\mathrm{m}$ $\mathrm{ZrO}_{2}$ close to $\mathrm{UO}_{2}$ confirmed Raman spectroscopy results previously reported in Ref. [17]. The exclusive presence of $\mathrm{m}-\mathrm{ZrO}_{2}$ in contact with $\mathrm{UO}_{2}$ contrasts data obtained by Raman spectroscopy on irradiated samples of $58.7 \mathrm{GWd} . \mathrm{t}_{\mathrm{U}}^{-1}[16,25]$ and $35.3 \mathrm{GWd} \cdot \mathrm{t}_{\mathrm{U}}^{-1}$ [25], which indicates the presence of $\mathrm{t}-\mathrm{ZrO}_{2}$ at the interface between fuel and internal zirconia layer. This supports the assumption of a $\mathrm{t}-\mathrm{ZrO}_{2}$ phase stabilization assisted by the fission products irradiation $[16,25]$ (based on two already known stabilization phenomena involving damages by ion irradiation [35-39] and chemical doping [40-42]), which is effective in PWR fuel rod and not with the model materials used in this experiment.

Indeed, in that case, a direct and tight bonded situation was observed between the $\mathrm{m}-\mathrm{ZrO}_{2}$ (formed by the solid-state oxidation of $\mathrm{Zy}-4$ by $\mathrm{UO}_{2}$ ) and the $\mathrm{UO}_{2}$, which are initially two distinct and independent materials. Furthermore, observation of a local $\mathrm{m}-\mathrm{ZrO}_{2}$ and $\mathrm{UO}_{2}$ crystalline lattice alignment (evidencing the existence of at least one hetero-epitaxy relationship between $\mathrm{m}-\mathrm{ZrO}_{2}$ and $\mathrm{UO}_{2}$ ), support the formation of iono-covalent bonds between the two materials.

By analogy, the same phenomenon could occur in both model materials and irradiated samples. The $\mathrm{t}-\mathrm{ZrO}_{2} \mid \mathrm{UO}_{2}$ bonding observed in irradiated samples, would therefore be due to the formation of iono-covalent bonds between the fuel and the internal zirconia layer. Moreover, as the internal zirconia region close to the fuel was found to have a tetragonal structure $\left(t-\mathrm{ZrO}_{2}\right)[13,16,25]$, whose lattice parameters are similar to those of $\mathrm{UO}_{2}$, but whose lattice symmetry is closer to $\mathrm{UO}_{2}$ than monoclinic zirconia (m- 
$\mathrm{ZrO}_{2}$ ), the formation of possible hetero-epitaxy relationships would be promoted in the case of $\mathrm{t}-\mathrm{ZrO}_{2}$.

Thus, these different results allow proposing that the fuelcladding bonding could be at least due to iono-covalent bonds between both compounds, leading to a chemical adhesion of the fuel with the internal zirconia layer.

\subsection{Indications about the fuel-cladding bonding evolution with burnup}

Characterization of high burnup PWR fuel rods samples helped to provide answers to the remaining uncertainty on how the chemical adhesion between $\mathrm{ZrO}_{2}$ and $\mathrm{UO}_{2}$ evolves with burnup.

Thus, cross sectional observations of the $\mathrm{ZrO}_{2} \mid \mathrm{UO}_{2}$ interface coupled with surface observations of the $\mathrm{ZrO}_{2}$ surface in a 64.5 GWd.t $t_{U}^{-1}$ sample revealed the highly wavy shaped of this interface, which appears to be composed of several "worms" like zirconia and fuel circumvolutions interlocked across the three dimensions. It is obvious that this complex interfacial morphology that appears at high burnup between fuel and zirconia can contribute to the fuelcladding bonding, and more specifically to the $\mathrm{ZrO}_{2} / \mathrm{UO}_{2}$ bonding, through a mechanical way. Indeed, in agreement with the physical anchorage theory of materials bonding [31], these interfacial $\mathrm{ZrO}_{2}$ and $\mathrm{UO}_{2}$ interlocked circumvolutions certainly match with a situation of physical anchorage of $\mathrm{ZrO}_{2}$ with $\mathrm{UO}_{2}$.

Based on those considerations, the following evolution of the $\mathrm{ZrO}_{2}-\mathrm{UO}_{2}$ bonding phenomenon can be proposed.

During in-reactor operation, the fuel-cladding contact, which leads to the solid state oxidation of the cladding by a portion of the "free" oxygen available in fuel (released during the fission events), also allows a chemical adhesion to occur between the internal zirconia and the fuel. This chemical adhesion, probably achieved through iono-covalent bonds between $\mathrm{ZrO}_{2}$ and $\mathrm{UO}_{2}$, would constitute the base of the $\mathrm{ZrO} / \mathrm{UO}_{2}$ bonding.

Then, the progressive morphological evolution with burnup of the $\mathrm{ZrO}_{2} \mid \mathrm{UO}_{2}$ interface, represented by the development of interfacial circumvolutions, which leads to the $\mathrm{ZrO}_{2} / \mathrm{UO}_{2}$ interlocking, will tend to mechanically strengthen their initial chemical adhesion through two phenomena. Firstly, the development of these circumvolutions will progressively increase the specific $\mathrm{ZrO}_{2} / \mathrm{UO}_{2}$ surface of contact and will therefore progressively boost their chemical adhesion. Secondly, it will also induce a mechanical strengthening of this chemical adhesion, due to the physical anchorage of the materials.

Thus, the whole fuel-cladding bonding will tend to strengthen with increasing burnup.

\section{Conclusion}

An attempt was made to identify the origins of the fuel-cladding bonding occurring in PWR fuel rods, its evolution, and the role of the interfacial zirconia layer in this phenomenon. Two PWR fuel rod samples of a $35.3 \mathrm{GWd} . \mathrm{t}_{\mathrm{U}}^{-1}$ moderate burnup and of a $64.5 \mathrm{GWd} . \mathrm{t}_{\mathrm{U}}^{-1}$ high burnup were specifically prepared and compared to a model materials diffusion couple.

Morphological observations on a $35.3 \mathrm{GWd} \cdot \mathrm{t}_{\mathrm{U}}^{-1} \mathrm{PWR}$ fuel rod sample provided original results evidencing a fuel-cladding adhesion phenomenon, through the zirconia layer that develops at the fuel|cladding interface. According to adhesion theories, the results suggest that iono-covalent bonds between $\mathrm{t}-\mathrm{ZrO}_{2}$ and $\mathrm{UO}_{2}$ would be responsible for their chemical adhesion.

Characterization of the metal|ceramic interfaces of a $Z y-4 /$ $\mathrm{UO}_{2.00} / \mathrm{Zy}-4 / \mathrm{UO}_{2.10} / \mathrm{Zy}-4$ model materials diffusion couple confirms that the hyper-stoichiometry of $\mathrm{UO}_{2.10}$ is mainly responsible for the $\mathrm{ZrO}_{2}$ formation (from the initial $\mathrm{Zy}-4$ oxidation). Transposition of this result to the PWR fuel rod case suggests that the available "free" oxygen released in the fuel by the fission events would be indeed mainly responsible for the cladding oxidation and the formation of the interfacial zirconia layer.

High-resolution observations of a recreated $\mathrm{m}-\mathrm{ZrO}_{2} \mid \mathrm{UO}_{2}$ bonded interface at the $\mathrm{Zy}-4 / \mathrm{UO}_{2.10}$ interface of model material diffusion couple reveal the presence of direct chemical bonds between the two oxides, obviously of iono-covalent nature due to the presence of local hetero-epitaxy relationships. By analogy, it is supposed that the same phenomenon could occur in PWR fuel rods and explain the $\mathrm{t}-\mathrm{ZrO}_{2} \mid \mathrm{UO}_{2}$ bonding at only $35.3 \mathrm{GWd} \cdot \mathrm{tu}^{-1}$.

At high burnup, complementary observations on a $64.5 \mathrm{GWd}^{-1} \mathrm{t}_{\mathrm{U}}^{-1}$ PWR fuel rod sample revealed a highly wavy shaped $\mathrm{ZrO}_{2} \mid \mathrm{UO}_{2}$ interfacial morphology, composed of $\mathrm{ZrO}_{2}$ and $\mathrm{UO}_{2}$ interlocked circumvolutions. This physical anchorage of the materials would be responsible for their mechanical bonding.

According to these results, a new and more accurate description of the pellet-cladding interaction ( $\mathrm{PCI}$ ) can be proposed, in addition to the increasing pellet-cladding friction coefficient that was initially used to describe the $\mathrm{PCI}$ as a function of burnup [3].

Thus, the in-reactor $\mathrm{ZrO}_{2}-\mathrm{UO}_{2}$ bonding could be considered as an adhesion phenomenon, owning two components. A first, of a chemical nature due to iono-covalent bonds between $\mathrm{t}-\mathrm{ZrO}_{2}$ and $\mathrm{UO}_{2}$. And a second of a mechanical nature, represented by the progressive development of the interfacial circumvolutions, progressively enhancing and strengthening the chemical one with burnup. A schematic representation of the evolution of both chemical and mechanical components of the fuel/cladding adhesion with burnup is proposed in Fig. 16.

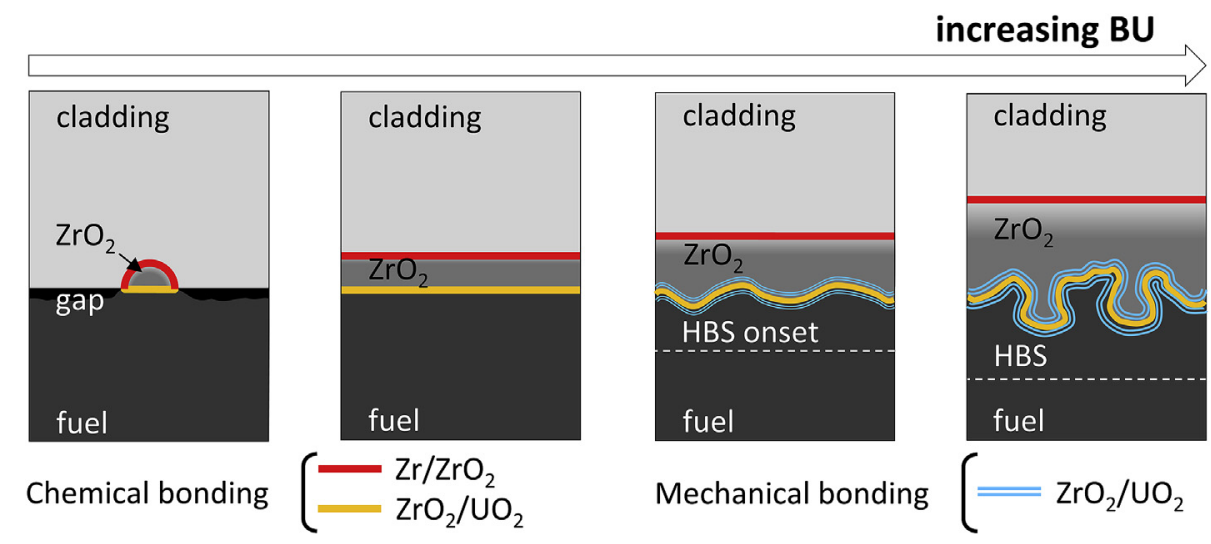

Fig. 16. Schematic representation of the evolution of the chemical and mechanical components of fuel-cladding adhesion with burnup. 
Complementary analyses, such as HRTEM observations, will be required on irradiated materials to confirm the observation of the $\mathrm{ZrO}_{2} \mid \mathrm{UO}_{2}$ chemical bonding that was made on model materials at high resolution, and ultimately to macroscopically quantify the whole fuel-cladding adhesion.

\section{Data availability}

The data that support the findings of this study are available from CEA, EDF and Framatome but restrictions apply to the availability of these data, which were used under license for the current study, and so are not publicly available. Data are however available from the authors upon reasonable request and with permission of CEA, EDF and Framatome.

\section{Acknowledgments}

EDF and Framatome are acknowledged for their technical and financial support. The authors would also like to thank Christine STRUZIK for the ALCYONE calculations, Stéphane REBOUL, Nicolas ROBERT, Paul BINET and Eric BROCHARD for the hot cell metallographic sample preparations and observations, Thierry BLAY for the hot cell SEM observations, Doris DROUAN for the SEM and EDS characterizations of model materials and Jean NOIROT for his expertise and fruitful discussions. Likewise, the authors would like to thank Martiane CABIE (CP2M, Marseille, France) for the TEM characterizations and Maëlenn AUFRAY (CIRIMAT, Toulouse, France) for fruitful discussions.

\section{References}

[1] H. Bailly, D. Ménessier, C. Prunier, R. Dautray, France, Commissariat à l'énergie atomique, Le Combustible nucléaire des réacteurs à eau sous pression et des réacteurs à neutrons rapides: conception et comportement, Eyrolles, Paris, 1996.

[2] B. Michel, C. Nonon, J. Sercombe, F. Michel, V. Marelle, Simulation of pelletcladding interaction with the PLEIADES fuel performance software environment, Nucl. Technol. 182 (2013) 124-137.

[3] J. Sercombe, I. Aubrun, C. Nonon, Power ramped cladding stresses and strains in 3D simulations with burnup-dependent pellet-clad friction, Nucl. Eng. Des. 242 (2012) 164-181.

[4] M.G. Adamson, E.A. Aitken, Chemical state and thermomigration behavior of fission product cesium in oxide fuel systems, Trans. Am. Nucl. Soc. 17 (1973) 195-196.

[5] J. Bazin, J. Jouan, N. Vignesoult, Behavior and physical-chemical state of fission products in fuel elements of PWR type reactors, CEA-BIST 196 (1974) 55-71.

[6] J. Bazin, J. Jouan, N. Vignesoult, Oxide-cladding reactions and their effect on water reactor fuel column behavior, in: Communications of the 1st European Nuclear Conference, Paris, France, 1975, pp. 21-25.

[7] D. Cubicciotti, J.E. Sanecki, Characterization of deposits on inside surfaces of LWR cladding, J. Nucl. Mater. 78 (1978) 96-111.

[8] H. Kleykamp, The chemical state of LWR high-power rods under irradiation, J. Nucl. Mater. 84 (1979) 109-117.

[9] J.O. Barner, M.E. Cunningham, M.D. Freshley, D.D. Lanning, High Burnup Effects Program-Final Report, Battelle Pacific Northwest Lab, 1990. DOE/NE/ 34046-1.

[10] K. Nogita, K. Une, Y. Korei, TEM analysis of pellet-cladding bonding layer in high burnup BWR fuel, Nucl. Instrum. Methods Phys. Res. Sect. B Beam Interact. Mater. Atoms 116 (1996) 521-526.

[11] K. Nogita, K. Une, formation of pellet-cladding bonding layer in high burnup BWR fuels, J. Nucl. Sci. Technol. 34 (1997) 679-686.

[12] N. Lozano, L. Desgranges, D. Aymes, J.C. Niepce, High magnification SEM observations for two types of granularity in a high burnup PWR fuel rim, J. Nucl. Mater. 257 (1998) 78-87.

[13] C. Gibert, Influence de l'irradiation et de la présence de lithium sur la nature cristallographique de la zircone dans le cadre de l'étude de la corrosion du zircaloy 4 en milieu réacteur à eau pressurisée, $\mathrm{PhD}$ thesis, Ecole centrale Paris, Châtenay-Malabry, France, 1998. http://www.theses.fr/1998ECAP0599.

[14] S. Van den Berghe, A. Leenaers, B. Vos, L. Sannen, M. Verwerft, Observation of a pellet-cladding bonding layer in high-power fuel, in: Seminar: Pellet-clad Interaction in Water Reactor Fuels, Aix-en-Provence, France, 2005 pp. 265-272.

[15] K.-T. Kim, UO $\mathrm{UO}_{2} / \mathrm{Zry}-4$ chemical interaction layers for intact and leak PWR fue rods, J. Nucl. Mater. 404 (2010) 128-137.

[16] C. Ciszak, M. Mermoux, S. Miro, G. Gutierrez, F. Lepretre, I. Popa, K. Hanifi I. Zacharie-Aubrun, L. Fayette, S. Chevalier, Micro-Raman analysis of the fuelcladding interface in a high burnup PWR fuel rod, J. Nucl. Mater. 495 (2017) 392-404.

[17] C. Ciszak, Etude de l'accrochage pastille/gaine des crayons combustibles des réacteurs à eau pressurisée, PhD thesis, Université de Bourgogne FrancheComté, Dijon, 2017. France, http://www.theses.fr/2017UBFCK045.

[18] M.W. Mallett, A.F. Gerds, A.W. Lemmon, D.L. Chase, The Kinetics of the Zirconium-Uranium Dioxide Reaction, 1955, pp. BMI-1028.

[19] A. Caneiro, M. Bonnat, J. Fouletier, Measurement and regulation of oxygen content in selected gases using solid electrolyte cells. IV. Accurate preparation of $\mathrm{CO}_{2}-\mathrm{CO}$ and $\mathrm{H}_{2} \mathrm{O}-\mathrm{H}_{2}$ mixtures, J. Appl. Electrochem. 11 (1981) 83-90.

[20] J. Fouletier, H. Seinera, M. Kleitz, Measurement and regulation of oxygen content in selected gases using solid electrolyte cells. II. Differential gauge, J. Appl. Electrochem. 5 (1975) 177-185.

[21] H. Matzke, Oxygen potential in the rim region of high burnup $\mathrm{UO}_{2}$ fuel, J. Nucl. Mater. 208 (1994) 18-26.

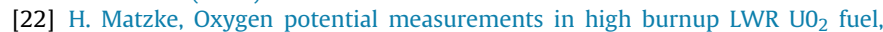
J. Nucl. Mater. 223 (1995) 1-5.

[23] H. Loukusa, T. Ikonen, V. Valtavirta, V. Tulkki, Thermochemical modeling of nuclear fuel and the effects of oxygen potential buffers, J. Nucl. Mater. 481 (2016) 101-110.

[24] J.-B. Minne, Contribution à la modélisation du couplage mécanique-chimique de l'évolution de l'interface pastille-gaine sous irradiation, PhD thesis, Université de Bourgogne, Dijon, 2013. France, http://www.theses.fr 2013 DIJOS085.

[25] N. Bérerd, Effets d'irradiation sur l'oxydation du zirconium et la diffusion de l'uranium dans la zircone, PhD thesis, Université Claude Bernard - Lyon I, Lyon, 2003. France, http://www.theses.fr/2003LYO10253.

[26] J. Noirot, L. Desgranges, J. Lamontagne, Detailed characterisations of high burn-up structures in oxide fuels, J. Nucl. Mater. 372 (2008) 318-339.

[27] E.F. Rauch, M. Véron, Automated crystal orientation and phase mapping in TEM, Mater. Char. 98 (2014) 1-9.

[28] K.L. Mittal, The role of the interface in adhesion phenomena, Polym. Eng. Sci. 17 (2004) 467-473.

[29] D.E. Packham, Theories of fundamental adhesion, in: L.F.M. da Silva, A. Öchsner, R.D. Adams (Eds.), Handb. Adhes. Technol., Springer Berlin Heidelberg, 2011, pp. 9-38.

[30] W. Gutowski, Thermodynamics of adhesion, in: L.-H. Lee (Ed.), Fundam. Adhes., Springer US, 1991, pp. 87-135.

[31] J.W. McBain, D.G. Hopkins, On adhesives and adhesive action, J. Phys. Chem. 29 (1924) 188-204.

[32] R.O.A. Hall, M.J. Mortimer, D.A. Mortimer, Surface energy measurements on $\mathrm{UO}_{2}$ - a critical review, J. Nucl. Mater. 148 (1987) 237-256.

[33] S. Meriani, C. Palmonari, Zirconia'88: Advances in Zirconia Science and Technology, Springer Science \& Business Media, 2012.

[34] P. Nikolopoulos, G. Ondracek, D. Sotiropoulou, Wettability and interfacial energies between zirconia ceramic and liquid metals, Ceram. Int. 15 (1989) 201-206.

[35] D. Simeone, J.L. Bechade, D. Gosset, A. Chevarier, P. Daniel, H. Pilliaire, G. Baldinozzi, Investigation on the zirconia phase transition under irradiation, J. Nucl. Mater. 281 (2000) 171-181.

[36] D. Simeone, D. Gosset, J.L. Bechade, A. Chevarier, Analysis of the monoclinic-tetragonal phase transition of zirconia under irradiation, J. Nucl. Mater. 300 (2002) 27-38.

[37] D. Simeone, G. Baldinozzi, D. Gosset, S. LeCaër, L. Mazerolles, Impact of radiation defects on the structural stability of pure zirconia, Phys. Rev. B 70 (2004) 134116.

[38] D. Simeone, G. Baldinozzi, D. Gosset, S. Le Caër, Phase transition of pure zirconia under irradiation: a textbook example, Nucl. Instrum. Methods Phys. Res. Sect. B Beam Interact. Mater. Atoms 250 (2006) 95-100.

[39] D. Simeone, G. Baldinozzi, D. Gosset, S. LeCaër, L. Mazerolles, I. Monnet S. Bouffard, Effect of the energy deposition modes on the structural stability of pure zirconia, Nucl. Instrum. Methods Phys. Res. Sect. B Beam Interact. Mater Atoms 266 (2008) 3023-3026.

[40] D. Michel, M.P. y Jorba, R. Collongues, Study by Raman spectroscopy of orderdisorder phenomena occurring in some binary oxides with fluorite-related structures, J. Raman Spectrosc. 5 (1976) 163-180.

[41] R.H.J. Hannink, P.M. Kelly, B.C. Muddle, Transformation toughening in zirconia-containing ceramics, J. Am. Ceram. Soc. 83 (2000) 461-487.

[42] C.H. Perry, D.-W. Liu, R.P. Ingel, Phase characterization of partially stabilized zirconia by Raman spectroscopy, J. Am. Ceram. Soc. 68 (1985) C-184. 